\title{
CASE-BASED REASONING UNTUK SISTEM DIAGNOSIS PENYAKIT MALARIA DI RSUD KABUPATEN PULAU MOROTAI
}

\section{CASE-BASED REASONING FOR MALARIA DISEASES DIAGNOSIS SYSTEM AT THE HOSPITAL OF MOROTAI ISLAND}

\author{
Miswar Papuangan ${ }^{1}$, Hean Rakomole ${ }^{2}$ \\ ${ }^{12}$ Program Studi Teknik Informatika, Fakultas Teknik \\ Universitas Pasifik Morotai \\ miswarpapuangan@gmail.com
}

\begin{abstract}
Abstrak
Malaria merupakan penyakit menular yang disebabkan oleh parasit plasmodium. Penyakit malaria menyebar lewat gigitan nyamuk yang terinfeksi parasit. Jika tidak ditangani dengan cepat dan tepat dapat menimbulkan komplikasi berat yang dapat berujung pada kematian. Infeksi malaria dapat terjadi hanya dengan satu gigitan nyamuk saja. Penuluaran dapat terjadi apabila ada kontak dengan darah penderita. Untuk mendiagnosis pasien penderita penyakit malaria dapat diketahui gejal-gejala yang dirasakan dan faktor resiko yang dialami. Penggunaan konsep case-based reasoning sebagai sistem untuk membantu melakukan diagnosis penyakit malaria. Fitur-fitur yang digunakan dalam melakukan diagnosis penyakit malaria diantaranya fitur usia, jenis kelamin, gejala, dan faktor resiko yang dialami. Algoritma nearest neighbor digunakan untuk menghitung tingkat kemiripan permasalahan baru dengan kasus yang tersimpn dalam basis kasus. Hasil pengujian menggunakan data rekam medik menunjukan bahwa sistem mampu mengenali tiga jenis penyakit malaria secara benar dengan tingkat akurasi sebesar 95,45\%.
\end{abstract}

Kata Kunci: Malaria, Nearest Neighbor, Case-Based Reasoning.

\begin{abstract}
Malaria is a deadly disease caused by the plasmodium parasite. This disease spreads through a bite of a particular type of mosquito that a parasite has infected. If it is not handled fast and appropriately, it can cause a serious complication that leads to death, except through blood contamination with the sufferer. To diagnose a patient infected from malaria can be recognized with the symptoms and factors of risk experienced by a patient. It uses a concept of casebased reasoning to assist in diagnosing malaria diseases such as age, gender, experienced symptoms, and risk. The nearest neighbor algorithm is used to calculate the similarity between new case problems and basis-saved cases. The
\end{abstract}


result used medic-recorded data, which showed the system could recognize three types of malaria disease correctly with the level of accuracy rate of $95.45 \%$.

\section{Keywords: Malaria, Nearest Neighbor, Case-Based Reasoning.}

\section{PENDAHULUAN}

Malaria merupakan penyakit menular yang disebabkan oleh parasite plasmodium. Penyakit ini menyebar lewat gigitan nyamuk yang terinfeksi parasite [1]. Jika tidak ditangani dengan cepat dan tepat dapat menimbulkan komplikasi berat yang dapat berujung pada kematian. Penularan dapat terjadi apabila ada kontak dengan darah penderita.

Infeksi malaria selama kehamilan dapat menyebabkan abortus dan berat bayi lahir rendah [1]. Kurang lebih 2,3 milyar (41\%) penduduk dunia beresiko terkena penyakit malaria. Diperkirakan setiap tahunya terdapat 300-500 juta kasus malaria dengan jumlah kematian bersikar 1,5 sampai 2,7 juta jiwa.

Menurut

World

Health

Organization (WHO), pada 2015 terdapat 214 juta kasus malaria baru di seluruh Dunia. Di tahun yang sama, 438.000 kasus malaria yang berujung pada kematian dengan Asia Tenggara sebanyak 7\%. Sedangkan di Indonesia tingkat penderita malaria dengan prevalensi mencapai $6 \%$.

Pemahaman masyarakat terhadap pentingnya menjaga sanitasi lingkungan agar terhindar dari sarang nyamuk yang menyebabkan terinfeksi malaria kurang teredukasi, seperti dibiarkan semak-semak yang tunbuh lebat di pinggiran rumah, selokan yang kotor dan dilumuri banyak bekas sampah, genangan air di samping rumah yang tentunya dapat berpotensi terjangkit penyakit malaria.

Faktor lingkungan juga berpengaruh besar terhadap penularan malaria, karena jika kondisi lingkungan memiliki tempat perindukan, maka nyamuk akan dapat berkembangbiak dengan mudah dan cepat.

Pemerintah melalui peraturan Presiden nomor 2 tahun 2015, tentang rencana pembangunan jangka menengah Nasional tahun 2015 sampai 2019, dimana penyakit malaria termasuk penyakit prioritas yang perlu dan harus ditanggulangi [2].

Penelitian ini dilakukan untuk merancang dan membangun sistem CBR untuk kepentingan membantu tenaga medis maupun asisten dokter dalam melakukan diagnosis pasien pederita penyakit malaria sehingga pasien dapat ditangani dengan mudah dan cepat.

CBR sebagai sistem diagnosis penyakit telah menghasilkan akurasi sistem yang baik. CBR untuk diagnosis pasien penderita penyakit THT pernah dilakukan dengan menghasilkan akurasi sebesar $91,89 \%$ [3]. 
Untuk mengukur tingkat kemiripan antar kasus dalam CBR yang pernah dilakukan, yakni menggunakan algoritma induksi dan nearest neighbor. Hasil mengindikasi bahwa algoritma nearest neighbor lebih baik dibandingkan dengan algoritma induksi dengan tingkat akurasi 53,8\% dan 100\% [4].

Metode CBR adalah salah satu sistem yang sering sering digunakan pada bidang kedokteran/medis untuk membantu melakukan diagnosis pasien. Sedangkan algoritma nearest neighbor untuk mengukur tingkat kemiripan antara permasalahan kasus baru dengan kasus yang pernah terjadi sebelumnya. Sistem ini diharapkan dapat membantu pihak RSUD dalam melakukan diagnosis awal pasien penderita penyakit malaria dengan keluhan terhadap gejala-gejala awal yang dirasakan.

Sistem yang dirancang dan dibangun ini bersifat fleksibel dan dinamis sehingga bisa digunakan sesuai dengan kondisi dilapangan yang terjadi.

\section{LANDASAN TEORI}

\section{Penyakit Malaria}

Malaria adalah penyakit yang disebabkan parasit dari genius plasmodium yang hidup dan berkembangbiak dalam sel darah merah manusia [1]. Masa inkubasi malaria dapat bervariasi, paling pendek pada plasmodium falsiparum, dan paling panjang pada plasmodium malariae.

Keluhan prodromal dapat terjadi sebelum demam, berupa kelesuhan, malaise, sakit kepala, berkeringat, menggigil, mual, muntah, nyeri pada tulang, sakit belakang, nyeri pada otot, anoreksia, diare, perut berasa tidak enak, dan kadang-kadang merasa dingin di punggung [5].

Gejala malaria paling cepat muncul sekitar satu minggu setelah digigit nyamuk anopheles yang terinfkesi. Umumnya masa inkubasi antara gigitan nyamuk malaria gejalan berlangsung 7-8 hari. Gejala khas malaria adalah adanya siklus menggigil, demam dan berkeringat yang terjadi berulang-ulang. Pengulangan bisa berlangsung tiap hari, dua hari seklai atau tiga hari sekali tergantung jenis malaria yang menginfeksi [6].

\section{Jenis Penyakit Malaria}

1. Malaria Falsiparum

Disebakan oleh Plasmodium falciparum. Gejala demam timbul intermiten dan dapat kontinyu. Malaria jenis ini menjadi malaria berat yang bisa menyebabkan kematian.

2. Malaria Vivaks

Disebabkan oleh plasmodium vivax. Gejala demam pada jenis malaria ini dapat berulang 
dengan interval bebas demam selama 2 hari.

3. Malaria Malariae

Disebabkan oleh plasmodium malariae. Jenis malaria ini demam terjadi berulang dengan interval bebas selama 3 hari.

\section{Case-Based Reasoning}

Case-base reasoning atau disingkat CBR merupakan metode penyelesaian yang menggunakan pengetahuan kejadian terdahulu untuk memecahkan permsalahan kasus baru [7]. CBR diselesaikan dengan melakukan pencocokan tingkat kemiripan dengan masalah kasus yang sudah terjadi sebelumnnya.

Terdapat empat tahapan proses dalam CBR [8].

1. Retrieve, mencari kasus terdahulu yang mirip dengan permasalahan kasus baru.

2. Reuse, menyalin atau menggabungkan solusi dari kasus terdahulu.

3. Revise, solusi dari kasus sebelumnya digunakan sebagai solusi kasus baru.

4. Retain, solusi kasus baru tersebut divalidasi.

\section{Data Flow Diagram (DFD)}

Data flow diagram merupakan alat yang digunakan untuk membuat diagram yang serbaguna. DFD terdiri dari notasi penyimpanan data, proses, aliran data, dan sumber masukan (entity) [9].

Entity Relationship Diagram (ERD)

ERD berisi kompenenkomponen himpunan entitas dan himpunan relasi yang masingmasing dilengkapi dengan atributatribut yang merepresentasikan seluruh fakta, dapat digambarkan dengan lebih sistematis [10].

\section{Relasi Tabel}

Relasi tabel merupakan kumpulan dari tabel-tabel yang saling berelasi, disusun secara logis, sehingga menghasilkan informasi yang bernilai dalam proses pengambilan keputusan [10].

\section{Representasi Kasus}

Pemecahan masalah sistem CBR bergantung pada representasi kasus yang memberikan informasi untuk penalaran kasus. kasus yang dimaksud adalah catatan rekam medik pasien penderita penyakit malaria. Kasus direpresentasikan dalam bentuk fitur-fitur yang disimpan dan merupakan parameter yang menjadi ciri dan penyelesaian dalam menangani masalah kasus.

Terdapat tiga kategori penilaian terhadap masing-masing fitur, yaitu:

1. Ketegori fitur usia. Kategori ini dinilai berdasarkan nilai usia yang terekam pada data pasien rawat inap pasien penderita penyakit malaria. 
2. Kategori fitur jenis kelamin. Penilaian jenis kategori ini, jika jenis kelamin laki-laki memiliki nilai 1 dan jenis kelamin perempuan memiliki nilai 0 .

3. Ketegori fitur gejala dan faktor resiko. Jika gejala atau faktor resiko muncul pada suatu kasus, maka bernilai 1. Jika gejala atau faktor tidak muncul pada suatu kasus, maka bernilai 0 .

Setiap atribut yang menyusun sebuah kasus mempunyai penlaian tersendiri. Jenis dan penilaian setiap ditunjukan pada tabel 1 .

Tabel 1. Jenis dan Penilaian Atribut

\begin{tabular}{|l|l|}
\hline \multicolumn{1}{|c|}{ Atribut } & \multicolumn{1}{c|}{ Nilai } \\
\hline Usia & Dalam satuan tahun \\
\hline Jenis kelamin & $\begin{array}{l}\text { Laki-laki }=1 \text { dan } \\
\text { Perempuan }=0\end{array}$ \\
\hline $\begin{array}{l}\text { Gejala dan faktor } \\
\text { resiko }\end{array}$ & Ya=1 dan Tidak $=0$ \\
\hline Diagnosis & $\begin{array}{l}\text { Malaria Falsiparum } \\
\text { Malaria Vivaks } \\
\text { Malaria Malariae }\end{array}$ \\
\hline
\end{tabular}

\section{Pengukuran Similaritas}

Pengukuran similaritas di lakukan untuk mendapatkan nilai untuk menentukan kemiripan antara permasalahan kasus baru dengan kasus yang tersimpan dalam basis kasus dengan membandingkat setiap fitur yang terdapat pada basis kasus.

Berikut adalah persamaan yang digunakan untuk mengukur similaritas, yaitu:

1. Similaritas lokal

Untuk data numerik, menggunakan fungsi similaritas lokal [11].

$$
f(s, t)=1-\frac{|s-t|}{R}
$$

$s, t$ adalah nilai fitur yang dibandingkan dan $R$ adalah range nilai fitur tersebut.

Untuk data boolean, menggunakan fungsi similaritas lokal [12]

$$
f(s, t)=\left\{\begin{array}{l}
1 \text { jika } s=t \\
0 \text { jika } s \neq t
\end{array}\right.
$$

2. Similaritas global

Pengukuran similaritas global digunakan untuk menghitung kasus baru dengan kasus-kasus yang tersimpan pada basis kasus. Fungsi similaritas global menggunakan teknik nearest neighbor [13].

$$
\operatorname{simNN}(S, T)=\frac{\sum_{i=1}^{n} f\left(S_{i} T_{i}\right) * W_{i}}{\sum_{i=1}^{n} W_{i}}
$$

$\operatorname{sim} N N(s, t)$ : similaritas global basis kasus $(s)$ dan kasus baru $(t)$

$t$ : target kasus/kasus baru

$s \quad$ : kasus yang ada pada basis kasus $n$ : banyaknya atribut pada tiap kasus

$i$ : atribut individu antara 1-n $f\left(S_{i}, T_{i}\right)$ : Fungsi similaritas lokal atribut ke- $i$ antara kasus $S$ dan kasus $T$

$W_{i}$ : Nilai bobot yang diberikan
pada atribut ke- $i$

Apabila nilai kemiripan tersebut kecil dari nilai ambang batas (threshold) yang ditentukan, yaitu $80 \%$, maka kasus tersebut akan disimpan di basis sebagai kasus yang akan direvisi oleh pakar sebagai solusi. Sedangkan output dari sistem yang dirancang adalah nama jenis penyakit malaria yang tingkat kemiripannya paling tinggi dengan permasalahan kasus baru. 


\section{METODE PENELITIAN}

\section{Deskripsi Sistem}

Sistem yang dirancang untuk melakukan diagnosis penyakit malaria dengan mengimplementasi sistem case-based reasoning (CBR).

Sedangkan algoritma nearest neighbor digunakan untuk menghitung nilai similaritas kasus baru dengan kasus yang ada pada basis kasus.

Secara garis besar digambarkan dalam diagram alir penelitian seperti ditunjukan pada gambar 1 .

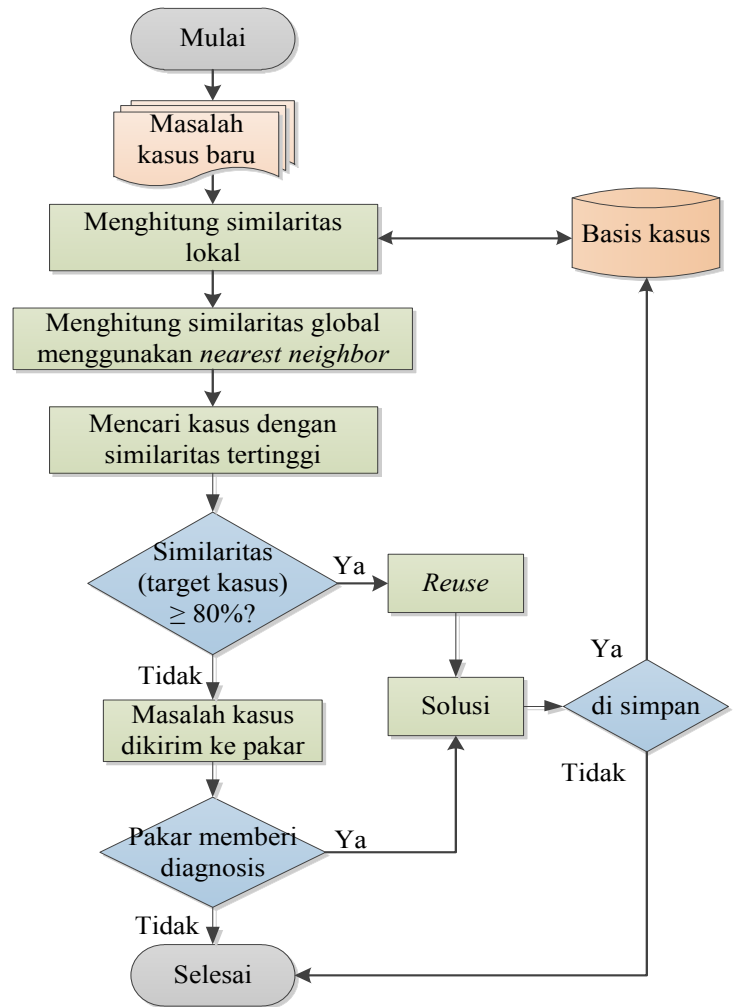

Gambar 1. Diagram Alir Penelitian

\section{Rancangan Arsitektur Sistem}

Pada tahap awal paramedis memasukkan permalasahan kasus baru seperti data pasien ke dalam sistem melalui modul input data barbasis graphical user interface (GUI). Kasus terdahulu yang memiliki nilai similaritas tertinggi dipilih sebagai solusi dari permasalahan kasus baru yang diinput.

Pada tahap reuse, dimana solusi kasus terdahulu digunakan untuk menyelesaikan permasalahan kasus baru. Kandidat solusi yang mempunyai nilai similaritas kurang dari threshold yang ditentukan, disimpan untuk kemudian dilakukan revisi oleh pakar. Jika nilai similaritas $\geq$ nilai threshold maka solusi dari kandidat solusi diambil sebagai solusi permasalahan kasus baru yang disampaikan kepada user melalui modul output. Rancangan arsitektur sistem CBR ditunjukan pada gambar 2 .

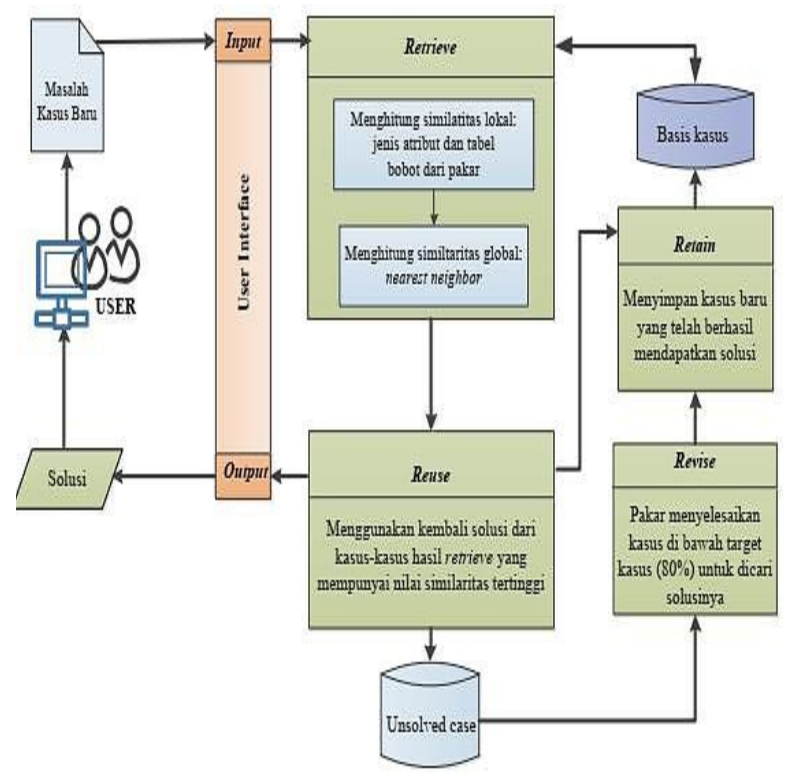

Gambar 2. Arsitektur Sistem CBR untuk Diagnosis Malaria

Diagram Konteks 
Sistem CBR diagnosis penyakit malaria terdiri dari tiga entitas pengguna sistem, diantaranya admin, pakar, dan paramedis.

Pakar menginput data pasien ke dalam sistem berupa data gejala, faktor resiko, data penyakit, data pembobotan, dan data basis kasus. pakar juga melakukan revisi kasus baru, jika nilai similaritas di bawa batas ambang. Sistem akan memberikan notifikasi ke pakar, jika terdapat kasus yang memerlukan revisi.

Paramedis menginputkan data identitas pasien dan gejalan serta faktorotassiskans resiko yang dialami. Sistem akang mengeluarkan hasil diagnosis ke paramedis. Paramedis bisa juga menyimpan permalahan solusi kasus baru ke dalam basis kasus. yang melakukan diagnosis. Paramedis juga dapat menyimpan permasalahan baru ke dalam sistem.

Admin merupakan entitas yang berhubungan dengan tata kelola pengguna sistem yang dibuat.

Diagram konteks ditunjukan seperti pada gambar 3 .

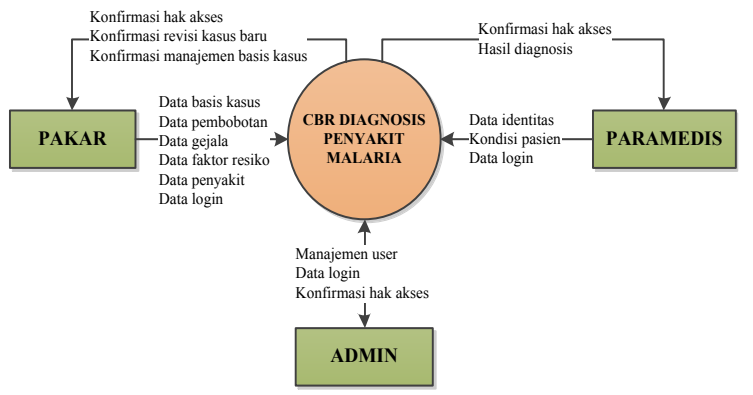

Gambar 3. Digram Konteks
DFD level merupakan uraian proses yang dibuat berdasarkan diagram konteks. Terdapat empat proses yang terjadi dalam sistem yaitu, proses manajemen hak akses, proses rekam data, proses konsultasi dan proses revisi. DFD level ditunjukan pada Gambar 4.

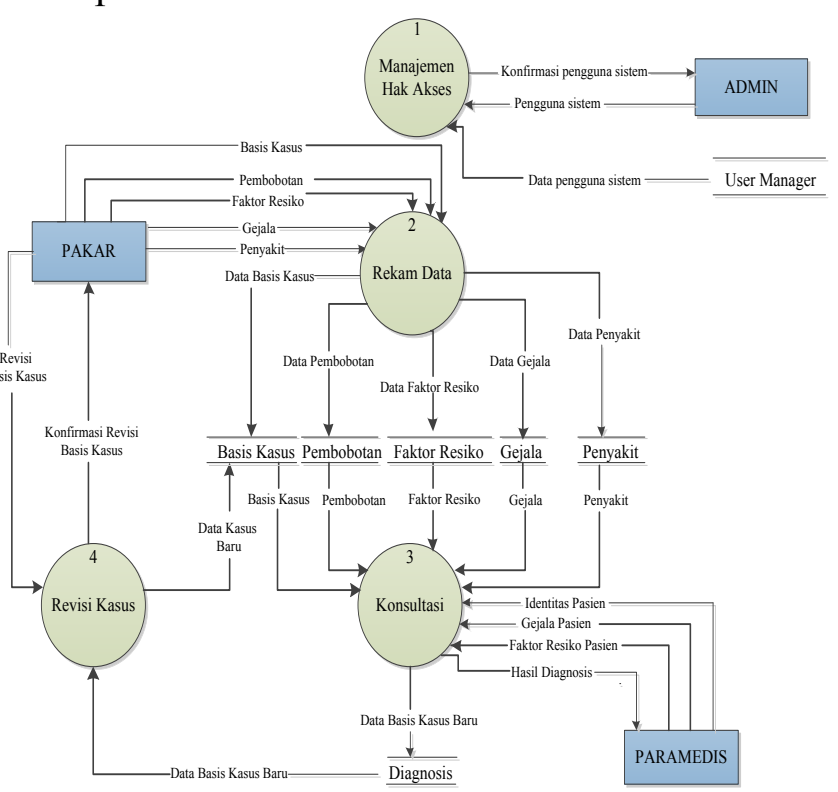

Gambar 4. DFD Level

\section{Relasi Antar Tabel}

Relasi tabel menggambarkan hubungan antar entitas yang terdapat dalam suatu basis data. Relasi tabel pada sistem ditunjukan pada gambar 4 .

\section{DFD Level}




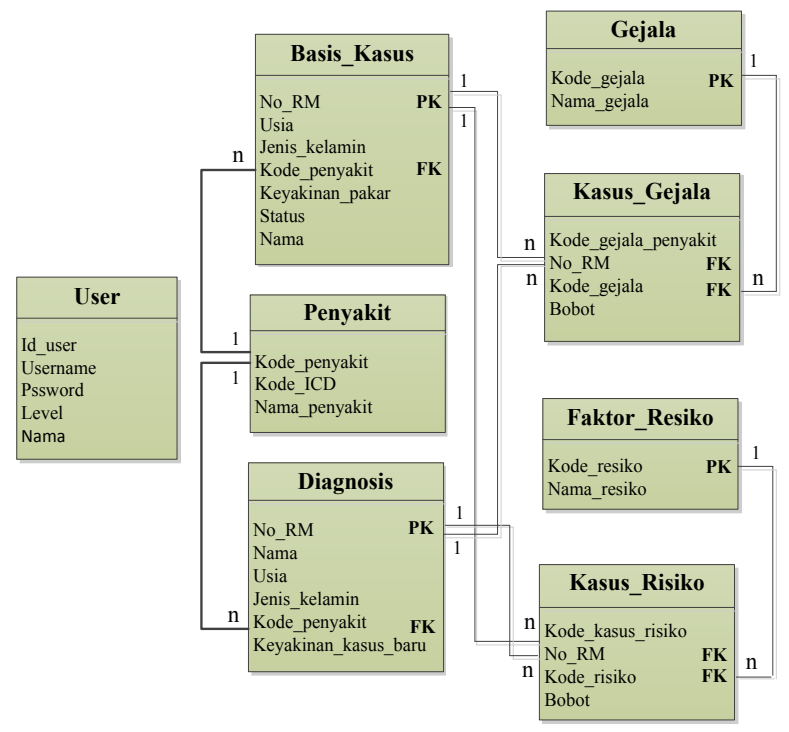

Gambar 4. Relasi Antar Tabel

\section{Data dan Metode Pengujian}

Data yang digunakan yaitu data rekam medik pasien rawat inap penderita penyakit malaria yang diperoleh dari Instalasi Catatan Medik RSUD Morotai. kasus yang dijadikan basis kasus sebanyak 54 kasus (70\%) dari total data kasus yang diperoleh. Tabel 2 menunjukan rekapitulasi data rekam medik yang digunakan sebagai data basis kasus.

Tabel 2. Data Basis Kasus

\begin{tabular}{|c|l|c|c|}
\hline No & Nama Penyakit & $\begin{array}{c}\text { Kode } \\
\text { ICD }\end{array}$ & $\begin{array}{c}\text { Jumlah } \\
\text { kasus }\end{array}$ \\
\hline 1 & $\begin{array}{l}\text { Malaria } \\
\text { Falsiparum }\end{array}$ & B50.9 & 24 \\
\hline 2 & Malaria Vivaks & B51.9 & 18 \\
\hline 3 & $\begin{array}{l}\text { Malaria } \\
\text { Malariae }\end{array}$ & B54 & 12 \\
\hline \multicolumn{2}{|c|}{ Total } & 54 \\
\hline
\end{tabular}

Sedangkan 22 data kasus (30\%) dari total keseluruhan data kasus digunakan sebagai data uji. Rekapitulasi data uji ditunjukan pada tabel 3 .

Tabel 3. Data Uji

\begin{tabular}{|c|l|c|c|}
\hline No & \multicolumn{1}{|c|}{$\begin{array}{c}\text { Nama } \\
\text { Penyakit }\end{array}$} & $\begin{array}{c}\text { Kode } \\
\text { ICD }\end{array}$ & $\begin{array}{c}\text { Jumlah } \\
\text { Kasus }\end{array}$ \\
\hline 1 & $\begin{array}{l}\text { Malaria } \\
\text { Falsiparum }\end{array}$ & B50.9 & 10 \\
\hline 2 & $\begin{array}{l}\text { Malaria } \\
\text { Vivaks }\end{array}$ & B51.9 & 7 \\
\hline 3 & $\begin{array}{l}\text { Malaria } \\
\text { Malariae }\end{array}$ & B54 & 5 \\
\hline \multicolumn{3}{|c|}{ Total } & 22 \\
\hline
\end{tabular}

Pengujian dilakukan dengan membandingkan hasil diagnosis sistem yang dibangun dengan diagnosis permasalahan kasus yang telah divalidasi pakar.

\section{HASIL DAN PEMBAHASAN}

\section{Antar Muka Sistem}

Form login merpupakan form yang menjadi antar muka pengguna sistem pertama yang menghubungkan pengguna dengan sistem. Tampilan form login ditunjukan pada gambar 5 .

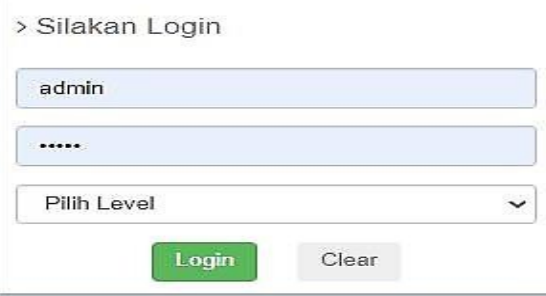

Gambar 5. Tampilan Form Login

Menu admin memungkinkan user untuk melakukan manajemen user. Admin dapat melakukan penambahan dan penghapusan 
pengguna sistem melalui form manajemen user. Tampilan form admin ditunjukan pada gambar 6 .

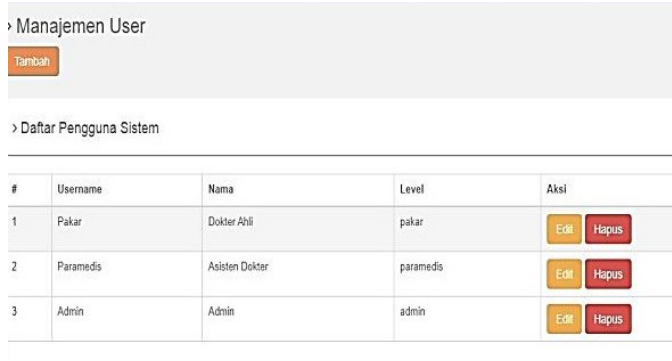

Gambar 6. Tampilan Form Manajemen user

Menu pakar memiliki tiga sub menu yaitu manajemen kasus, revisi kasus dan ubah bobot. Tampilan form menu pakar ditunjukan pada gambar 7

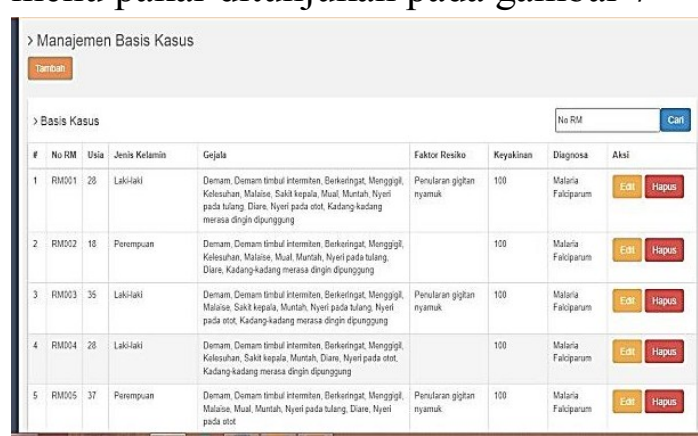

Gambar 7. Tampilan Menu Manajemen Kasus

Menu pakar juga terdapat manajeman inputan penyakit, gejala, dan faktor resiko. Tampilan inputan penyakit ditunjukan pada gambar 8 dan 9.

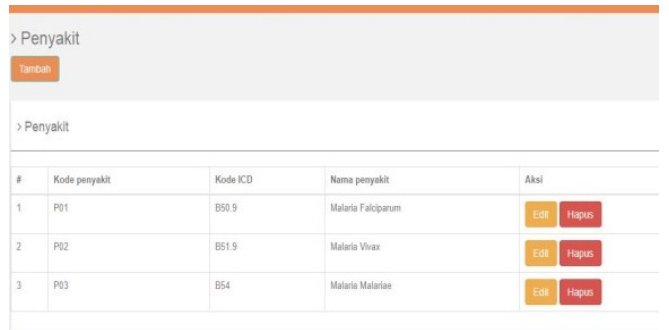

Gambar 8. Tampilan Data Inputan

Penyakit

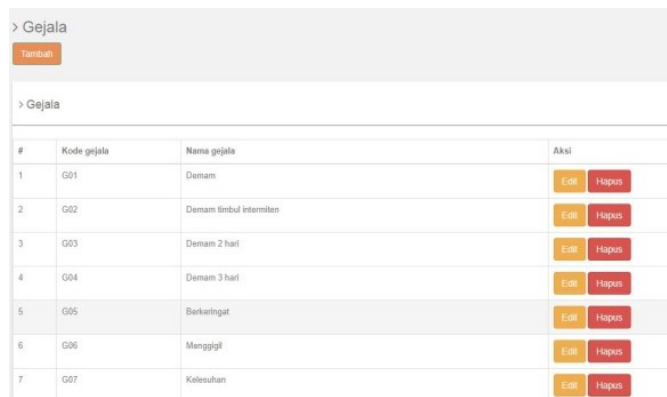

Gambar 9. Tampilan Data Inputan

$$
\text { Gejala }
$$

Menu paramedis terdiri dari menu diagnosis. Proses diagnosis mencakup prose memasukkan data pasien, proses perhitungan similaritas, proses penyimpanan permasalahan kasus baru, dan proses menampilkan hasil diagnosis. Form diagnosis ditunjukan pada gambar 10 .

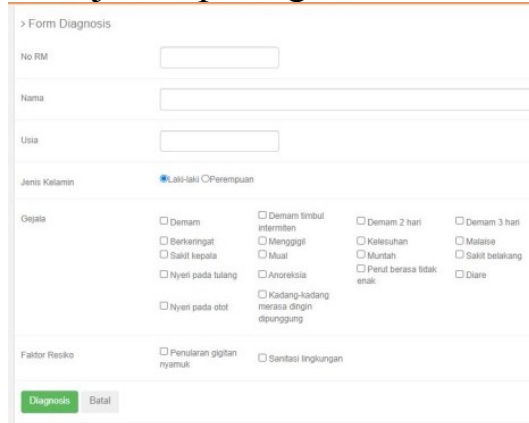

Gambar 10. Tampilan Form Diagnosis

Setelah melalui proses diagnosis, maka solusi yang dihasilkan adalah solusi dari sistem. Solusi ini ditampilkan kepada user melalui form hasil diagnosis, seperti ditunjukan pada gambar 11 . 


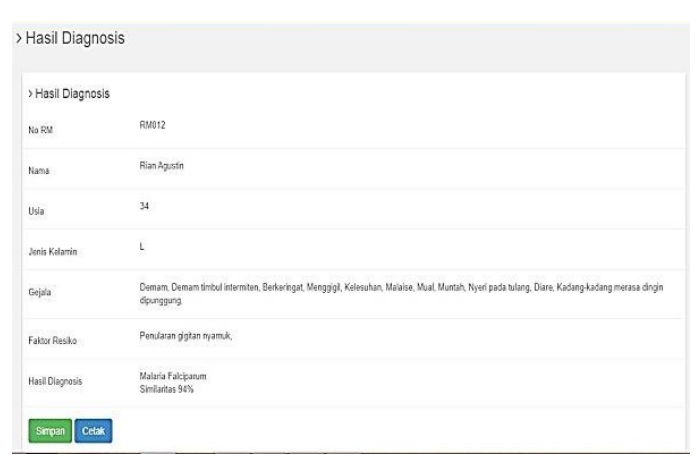

Gambar 11. Tampilan Hasil Diagnosis

Hasil diagnosis menunjukan jenis penyakit malaria yang diderita pasien dengan nilai similaritas tertinggi terhadap kasus sebelumnya. Permasalahan kasus yang memiliki fitur lengkap dapat disimpan untuk menambah basis kasus.

Hasil pengujian dari keseluruhan data yang diujikan diperoleh satu permasalahan yang mempunyai nilai similaritas bawah $80 \%$, sehingga tidak dapat dikategorikan ke dalam jenis penyakit malaria. Hasil pengujian untuk setiap data ditunjukan pata tabel 4 (confusion matrix) [14], dan ilustrasikan ke dalam bentuk grafik oleh gambar 12.

Pada ilustrasi grafik, sumbu vertikal menunjukkan jumlah diagnosis yang benar sesuai dengan jenis penyakit malaria, sedangkan untuk sumbu horizontal menunjukkan jenis penyakit malaria.

Tabel 4. Confusion Matrix Hasil Pengujian

\begin{tabular}{|c|c|c|c|c|}
\hline \multirow{2}{*}{ No } & \multirow{2}{*}{$\begin{array}{c}\text { Jenis } \\
\text { penyakit }\end{array}$} & \multicolumn{3}{|c|}{ Hasil Diagnosis } \\
\cline { 3 - 5 } 1 & $\begin{array}{l}\text { Malaria } \\
\text { Falsiparum }\end{array}$ & 9 & 1 & 10 \\
\hline
\end{tabular}

\begin{tabular}{|c|l|c|c|c|}
\hline 2 & $\begin{array}{l}\text { Malaria } \\
\text { Vivaks }\end{array}$ & 7 & 0 & 7 \\
\hline 3 & $\begin{array}{l}\text { Malaria } \\
\text { Malariae }\end{array}$ & 5 & 0 & 5 \\
\hline \multicolumn{2}{|l|}{ Total } & 21 & 1 & 22 \\
\hline
\end{tabular}

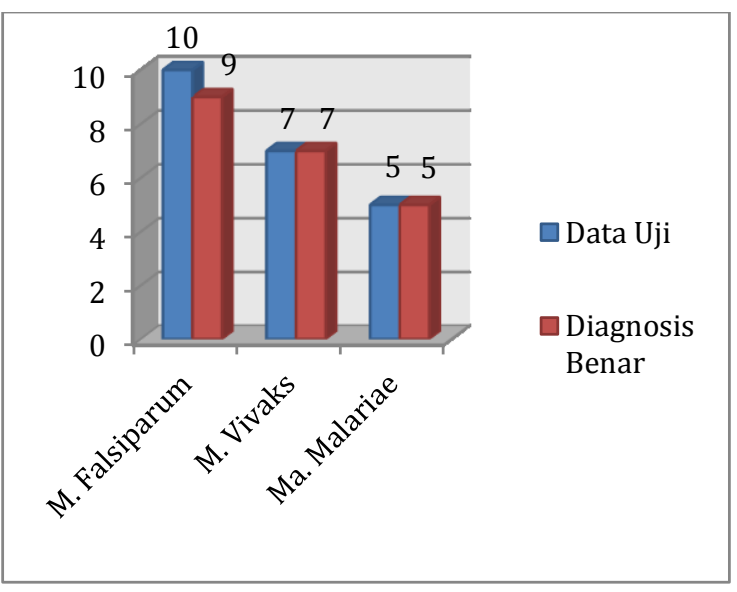

Gambar 12. Grafik Hasil

Pengujian

\section{Pengujian Akurasi Sistem}

Akurasi merupakan tingkat kedekatan pengukuran kuantitas terhadap nilai sebenarnya. Pengujian akurasi sistem dilakukan dengan membandingkan jumlah diagnosis benar oleh sistem dengan jumlah data uji.

Unjuk kerja sistem dihitung dengan menggunakan persamaan [15].

$$
\begin{gathered}
\text { Akurasi }=\frac{\sum \text { diagnosis benar }}{\sum \text { data uji }} \times 100 \% \\
\text { Akurasi }=\frac{21}{20+1} \times 100 \%=95,45 \%
\end{gathered}
$$

Hasil Pengujian menunjukan persentase unjuk kerja sistem dalam mengenali jenis penyakit malaria secara benar dengan nilai akurasi sebesar 90,91\%. 


\section{KESIMPULAN}

Penelitian ini menghasilkan sistem case-based reasoning untuk melakukan diagnosis penyakit malaria dengan pengukuran similaritas kasus menggunakan algoritma nerest neighbor.

Dari hasil perancangan sistem CBR diagnosis malaria hingga proses pengujian sistem yang telah dilakukan terhadap data uji penyakit malaria, sistem menunjukan unjuk kerja dengan nilai tingkat akurasi sebesar 95,45\%.

\section{DAFTAR PUSTAKA}

[1] Sutanto dan Cania, B. E., 2017. Faktor Lingkungan, Perilaku dan Penyakit Malaria. Jurnal Agromedia Unila, 4 (1): 173184.

[2] Anonim. 2017. Buku Saku Penatalaksanaan Kasus Malaria. Ditjen Pencegahan dan Pengendalian Penyakit. Kementerian Kesehatan RI, Jakarta.

[3] Pressman, R. S., 2012. Rekayasa Perangkat Lunak Edisi 7. Gramedia, Yogyakarta.

[4] Salem, A. B. M., Roushdy, M., dan Hodhod, R. A., 2005. A CaseBased Expert System For Supporting Diagnosis of Heart Disease. AIML Journal. 5 (1): 33-39.

[5] Harijanto, P. N., Nugroho, A., dan Gunawan, C. A. 2008. Malaria: dari Molekul dan Klinis. Edisi ke-2. EGC. Jakarta.
[6] Anonim. 2014. Infodatin Pusat Data dan Informasi Kementerian Kesehatan RI. Situasi Malaria di Indonesia. Jakarta.

[7] Pal, S. K., dan Shiu, S. C. K. 2004. Foundations of Soft Case-Based Reasoning. Wiley-Interscience Publication.

[8] Aamodt, A., dan Plaza, E. 1994. Case-Based Reasoning: Foundational Issues, Methodological Variations, and System Approaches. AI Communication IOS Press. 7 (1): 39-59.

[9] Yakub. 2012. Pengantar Sistem Informasi. Graha Ilmu, Yogyakarta, ISBN 978-979756-807-8.

[10] Whitten, J. L., Bentley, L. D., dan Dittman, K. C., 2014. Metode Desain dan Analisis Sistem 6. ANDI, Yogyakarta. [11] Jha, M.K., Pakhira, D., dan Chakraborty, B., 2013. Diabetes Detection and Care Applying CBR Techniques, IJSCE, 6, 2, 132-137.

[12] Nurdiansyah, Y., dan Hartati, S., 2014. Case-Based Reasoning Untuk Pendukung Diagnosa Gangguan Pada Anak Autis, Tesis, Ilmu Komputer, Universitas Gadjah Mada, Yogyakarta.

[13] Ong, L., S., Shepherd, B., Tong, L. C., Choen, F. S., 
Ho, H. K., Tang. C. L., Ho. Y.

S., dan Tan. K., 1997, The

Colorectal Cancer Recurrence

Support (CARES) System, Artificial intelligence in

Medicine Elsevier, vol 11, 175188.

[14] Bramer, M., 2007, Principles of

Data Mining, Springer-Verlag, London.

[15] Whitten, I.H., dan Frank, E., 2005, Data Mining: Practical Machine Learning Tools and Techniques, 2, Morgan Kaufmann Publisher, San Francisco 